\title{
FAKTOR PENGARUH DAYA TARIK VISUAL BRAND ORGANICUP TERHADAP BRAND AWARENESS MAHASISWA UNIVERSITAS KATOLIK SOEGIJAPRANATA
}

\author{
Sari Dian Saputri \\ saridiansss@gmail.com \\ Universitas Katolik Soegijapranata \\ Jl. Pawiyatan Luhur IV/1, Bendan Dhuwur, Semarang
}

\begin{abstract}
ABSTRAK
Penelitian tentang Faktor Pengaruh Daya Tarik Visual Brand OrganiCup Terhadap Brand Awareness Mahasiswa Unika Soegijapranata Semarang ini bertujuan untuk mengungkap faktor-faktor apa saja yang menjadi daya tarik visual dalam media promosi OrganiCup dan brand image dari OrganiCup di mata masyarakat. Penelitian ini menggunakan metode penelitian kualitatif deskriptif dengan data yang diperoleh melalui wawancara, kajian literatur berupa artikel, website, jurnal penelitian dan informasi terkait. Hasil dari penelitian ini adalah desain pada media promosi OrganiCup sudah mendapatkan brand awareness dari mahasiswa Universitas Katolik Soegijapranata.
\end{abstract}

Kata Kunci: menstrual cup, organicup, produk sanitasi, desain komunikasi visual, kesadaran merek.

\section{PENDAHULUAN}

Setiap perempuan di usia remaja memasuki masa pubertas yaitu salah satunya mengalami menstruasi. Oleh karena itu perusahaan produk kewanitaan berlomba-lomba untuk memenuhi kebutuhan mereka dengan membuat suatu produk kewanitaan saat menstruasi. Dalam memenangkan persaingan bisnis, peran branding itu hal yang penting. Mempunyai sebuah daya tarik dan kelebihan seperti kualitas produk sehingga konsumen tertaik untuk menggunakan produk tersebut.

Untuk membuat daya tarik visual dapat diterima secara maksimal, didalamnya terdiri dari gabungan unsurunsur grafis. Dalam daya tarik visual,

\footnotetext{
${ }^{1}$ Chistine Suharto Cenadi (2020), Peranan Desain

Kemasan Dalam Dunia Pemasaran, h.98
}

adanya hubungan antara faktor emosi dan psikologis yang letaknya di bawah sadar manusia. Sehingga dapat terciptanya desain yang baik, mampu mempengaruhi konsumen untuk menyampaikan respon positif tanpa disadarinya. Dengan adanya daya tarik tertentu, dapat dipastikan dapat mempengaruhi konsumen secara psikologis. ${ }^{1}$

Remaja akhir perempuan terutama mahasiswa dapat dengan mudah mengikuti pengaruh gaya hidup, trend dan sesuatu yang sedang viral. Selain itu, rasa penasaran dan ingin mencoba hal baru terhadap sesuatu produk. Perempuan di Indonesia sudah tisak asing lagi dengan produk kewanitaan atau alat sanitasi yang 
digunakan untuk kesehatan dan kebersihan saat mengalami menstruasi. Selain pembalut, terdapat jenis alat sanitasi yang mulai digunakan oleh perempuan di Indonesia, yaitu menstrual cup yang mempunyai bentuk seperti corong minyak atau cangkir, memiliki ukuran sesuai kebutuhan perempuan yang sudah menikah ataupun belum dan juga terbuat dari Medical Grade Silicon yang terbukti aman untuk tubuh. Namun, cara penggunaan tampon dan menstrual cup yang terbilang sama, masih sering dianggap tabu dalam perspektif virginitas atau keperawanan. Karena masih banyak yang beranggapan bahwa saat memasukan sesuatu ke dalam vagina dapat merusak selaput dara, yang dapat mengakibatkan tidak perawan lagi. Menurut Dokter Fadhli Rizal Makarim, tidak adanya merusak selaput dara saat menggunakan tampon atau menstrual cup. ${ }^{2}$

Sejalan dengan hal tersebut, perusahaan yang dinamis akan selalu berinovasi supaya dapat mencapai kemajuan bisnisnya. Merek atau brand untuk mendapatkan sebuah peluang, dituntut untuk menempatkan daya tarik produk, brand awareness dan promosi. Produk yang dipasarkan dengan tepat sasaran, diharapkan mendapatkan respon positif dari konsumen dan keuntungan perusahaan untuk memperluas pasar serta brand awareness yang tumbuh di masyarakat. Dalam hal ini, kegiatan desain komunikasi visual suatu perusahaan setidaknya memiliki strategi bagaimana menghasilkan daya tarik visual yang berpengaruh pada brand awareness dan promosi yang sesuai dengan segmentasi pasar. Sehingga, perusahaan dapat memenuhi kebutuhan manusia yang belum tercukupi.

\footnotetext{
${ }^{2}$ Gintari Dian Ayuranti (2020), Perancangan Buku Visual Edukasi Menstrual Hygiene, h.4
}

Selain menstrual cup yang berfungsi untuk menampung darah saat mengalami menstruasi, OrganiCup juga menghadirkan produk-produk seperti OrganiWipes dan OrganiWash yang berfungsi untuk membantu membersihkan menstrual cup saat atau setelah menstruasi. OrganiCup sudah terdaftar di The Vegan Society dan AllergyCertified pada tahun 2017 dan telah memenangkan penghargaan "Best New Product" dan "Product Of The Year" pada tahun 2015. Produk sanitasi tersebut menggunakan merek dagang logo yang menyerupai siklus menstruasi yang sudah dipatenkan. Untuk mendapatkan produknya, dapat memesan melalui website resmi OrganiCup, dan untuk di Indonesia dapat ditemukan di website yang menjual produk-produk ramah lingkungan seperti Sustaination dan blukstore atau toko klontong Ranah Bhumi yang menjual produk serupa.

Berdasarkan uraian di atas, maka penulis tertaik untuk menganalisa dengan mengambil judul "Pengaruh Daya Tarik Visual Brand OrganiCup Terhadap Brand Awareness Mahasiswa Universitas Katolik Soegijapranata".

\section{METODE}

Dalam penelitian ini menggunakan pendekatan kualitatif. Pendekatan kualitatif digunakan untuk menemukan, mengungkap dan mendeskripsikan faktor daya tarik visual pada brand OrganiCup terhadap brand awareness mahasiswa Unika Soegijapranata.

Data yang dibutuhkan penulis dalam penelitian berupa penjelasan deskriptif tentang daya tarik visual pada OrganiCup. Strategi pengumpulan data primer yang diperoleh dari wawancara kepada responden perempuan berusia 
18 - 25 tahun mengenai produk sanitasi, menstrual cup dan media promosi OrganiCup. Data sekunder diperoleh dari berbagai kajian literature berupa artikel, website, jurnal penelitian dan informasi terkait.

\section{Purposive Sampling}

Target yang dituju adalah wanita berusia 18-25 tahun, dengan status mahasiswa Unika Soegijapranata dengan jumlah sample sebanyak 25 orang. Dilakukannya metode penelitian ini guna mengetahui sejauh apa Brand 'OrganiCup' dimata mahasiswa Unika Soegijapranata.

\section{KAJIAN TEORI}

\section{Definisi Brand (merek)}

Brand atau merek merupakan hal yang penting dalam berbisnis. Dalam hal ini, penulis ingin membahas mengenai merek atau brand dari OrganiCup. Definisi brand atau merek, menurut $\mathrm{KBBI}$ tanda yang dikenakan oleh pengusaha (pabrik, produsen, dan sebagainya) pada barang yang dihasilkan sebagai tanda pengenal; cap (tanda) yang menjadi pengenal. Sebuah perusahaan dapat dikatakan sukses dan berhasil dapat dilihat dari seberapa brand atau merek yang mampu membedakan dengan brand lainnya.

Berdasarkan yang tertulis di Undang-Undang No. 1 Pasal 1 ayat 1 tahun 2001, brand atau merek adalah sebuah tanda yang berupa gambar, tulisan, nama, kata dan huruf-huruf yang dikombinasikan dan unsur-unsur tersebut digunakan sebagai pembeda dalam kegiatan perdagangan barang dan jasa.

Suatu brand dan jasa yang diperdagangkan, membutuhkan pengelompokan kualitas. Menurut Prof $\mathrm{R}$ Soekardono, brand atau merek adalah suatu tanda yang memberikan ciri tertentu pada sebuah barang atau produk tertentu, di mana bertujuan digunakan untuk menjamin kualitas barang tertentu saat dibandingkan dengan barang yang sama dan sejenis dari perusahan yang berbeda.

Sebuah produk harus menunjukkan kualitas dari produk itu sendiri, merek juga harus memiliki ciri khas yang bertujuan merek mudah diingat oleh konsumen. Untuk menjadi sebuah merek yang baik, merek memiliki beberapa syarat.

Menurut Rangkuti (dalam The Power of Brand 2004:37) sebuah merek harus:

a. Memiliki nama yang dapat menunjukkan manfaat dan mutu produk merek

b. Merek harus memiliki nama yang singkat dan mudah diingat oleh konsumen

c. Memiliki nama yang khas supaya berbeda dari yang lain

d. Mudah diterjemahkan dalam bahasa asing

e. Nama merek harus bisa memperoleh hak untuk didaftarkan dan mendapat perlindungan hukum

\section{Teori Brand Awareness}

Perusahaan seperti OrganiCup yang berasal dari luar negeri dan baru masuk ke Indonesia, sangat penting mempunyai sebuah brand awareness atau kesadaran merek, karena banyaknya pesaing menstrual cup dari brand local. Dengan adanya brand awareness dapat membangun merek atau brand OrganiCup agar lebih dikenal masyarakat, khususnya target audiens.

Salah satu indikator yang penting untuk menciptakan sebuah brand awareness yaitu merek atau brand itu sendiri. Dalam Strategi Menaklukan Pasar Melalui Riset Ekuitas dan Perilaku 
Merek, brand awareness memperlukan sebuah tindakan yang sifatnya berkelanjutan untuk memastikan bahwa konsumen tidak mengetahui bila adanya sebuah merek tertentu atau serupa yang telah dikenal sebelumnya, sehingga dapat meyakinkan konsumen bahwa merek ini merupakan satu-satunya merek dalam produk tersebut. (Durianto Dkk, 2001:4).

Oleh karena itu, dari definisi di atas, brand awareness atau kesadaran merek adalah kemampuan suatu merek atau brand untuk diingat oleh konsumen dengan tujuan untuk melakukan pembelian produk dari merek tersebut.

\section{Teori Daya tarik Visual}

Untuk menciptakan dan menampilkan kesan visual yang optimal, perlu adanya dipadukan mencakup bentuk, warna, ilustrasi, teks, tata letak dan merek. Daya tarik berhubungan dengan faktor emosi atau psikologis yang terletak dibawah alam sadar manusia. Sebagai contoh, desain kemasan yang menarik konsumen akan membelinya walaupun produk tersebut belum tentu lebih baik dari produk lainnya.

Suatu brand atau merek harus berupaya mengenalkan produknya melalui sebuah iklan dan promosi sehingga timbul akibat daya tarik yang ditimbulkan produk itu sendiri yang bertujuan untuk menarik konsumen dan menimbulkan minat beli.

Promosi penjualan harus memperhatikan faktor-faktor yang mempengaruhi daya tarik visual, yaitu:

\section{Warna}

\begin{tabular}{lcr}
\multicolumn{1}{c}{ Warna } & berfungsi & untuk \\
mengidentifikasi & produk & untuk \\
membedakan & dengan produk pesaing, \\
menimbulkan & pengaruh & sehingga \\
meningkatkan & selera & konsumen
\end{tabular}

terharap produk misalnya makanan, untuk menciptakan suatu citra atau image dari suatu produk.

\section{Merk atau Logo}

Sebuah brand yang memiliki logo yang baik akan meningkatkan daya tarik konsumen dan menaikkan gengsi atau status konsumen.

Syarat untuk dapat dikatakan logo yang baik yaitu mengandung keaslian atau original, mudah dibaca atau diucapkan, mudah diingat, sederhana, tidak mengandung konotasi yang negatif, serta mudah digambarkan. Sehingga, dengannya merk atau logo ini, konsumen dapat dengan mudah mengenali.

\section{Ilustrasi}

Sebuah alat komunikasi yang menggunakan bahsa universal agar dapat menyampaikan pesan dengan perbedaan bahasa melalui sebuah gambar. Dalam hal ini, sebuah ilustrasi juga termsuk salah satunya fotografi untuk menarik konsumen.

\section{Tipografi}

Sebuah teks yang terdapat pada suatu produk yang berupa pesan-pesan untuk menjelaskan produk tersebut. Dan juga membuat konsumen untuk mengambil tindakan sesuai harapan dari perusahaan, yaitu menimbulkan minat beli.

\section{Tata Letak}

Tata letak dalam sebuah produk, meliputi semua unsur grafis yaitu warna, bentuk, merek ilustrasi, tipografi yang dijadikan satu menjadikan suatu kesatuan baru.

Hal-hal yang perlu diperhatikan dalam tata letak, yaitu: keseimbangan, titik pandang dengan menjadikan satu 
unsur paling menarik, perbandingan ukuran yang serasi dan pas, serta tata urutan alur keterbatasan yang sesuai.

Selain itu, daya tarik visual produk terhadap promosi penjualan diakibatkan oleh intern dan ekstern. Sebab intern ditumbulkan dalam perusahaan tersebut, yaitu desain produk, harga jual, ketersediaan bahan baku, kualitas produk, variasi kemasan, inovasi, iklan, serta merek itu sendiri. Sedangkan sebeb ekstern merupakan faktor diluar kekuasaan perusahaan, yaitu selera konsumen, perilaku konsumen, strategi pengembangan produk baru, kualitas SDM, strategi pemasaran, citra atau image perusahaan dan tindakan pesaing.

\section{ANALISIS DATA}

\section{Sejarah OrganiCup}

Pada tahun 1860-an dan 1870-an di Amerika Serikat, Menstrual Cup disebut "Catamenial Sacks". Namun sebagian masyarakat tidak menerimanya karena penggunaannya yang ribet. Menstrual Cup modern dikenalkan oleh aktris Amerika bernama Leona Chalmers yang memberi nama dengan "Tass-ette" pada tahun 1963.

Menstrual Cup saat ini re-usable menggunakan bahan Medical Grade Silicon yang terbukti aman untuk tubuh. Menstrual Cup mulai dikenal di Indonesia pada tahun 2018. Melalui situs Sustaination sebuah website yang menjual produk-produk reusable dan ramah lingkungan, dan juga termasuk brand OrganiCup.

Menstrual Cup merupakan sesuatu yang baru di Indonesia, terdengar tabu dan masih terjerat dalam stigma negative di masyarakat. OrganiCup merupakan brand asal
Denmark yang berdiri tahun 2012, yang kini sudah cukup dikenal di Indonesia.

OrganiCup merupakan sebuah merek atau brand yang megusung konsep "The \#NewPeriod" yaitu alat sanitasi kesehatan dan kebersihan yang sudah memenangkan penghargaan sebagai pengganti pembalut dan tampon. Dikutip dari situs resminya, OrganiCup selalu berpegang teguh pada 4 prinsipnya, yaitu: tidak ada yang harus ditahan oleh tubuh wanita, percaya bahwa porduknya tidak boleh mengandung bahan kimia berbahaya atau menyerap sekresi tubuh alami, menstruasi seharusnya tidak menjadi penyebab polusi dan seharusnya tidak menjadi sumber rasa malu.

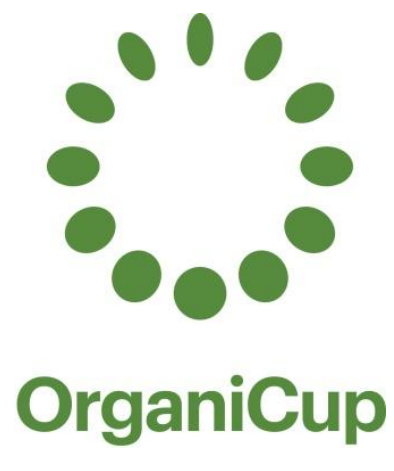

Gambar 1: Logo OrganiCup

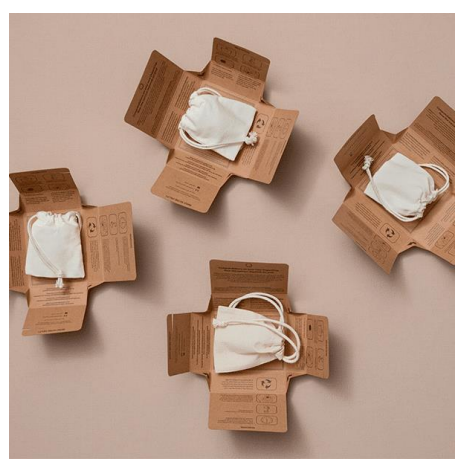

Gambar 2: Packaging OrganiCup 


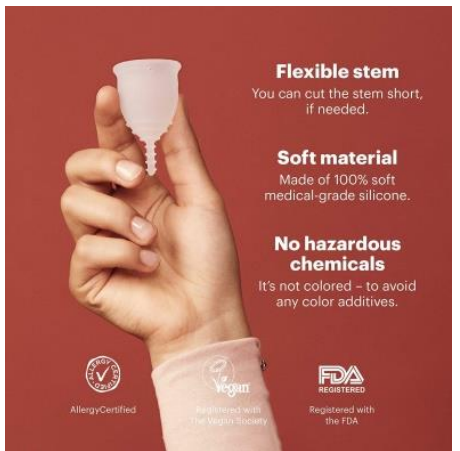

Gambar 3: Desain Promosi OrganiCup

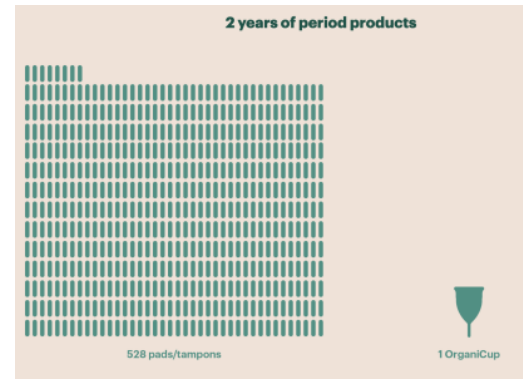

Gambar 4: Desain Promosi OrganiCup

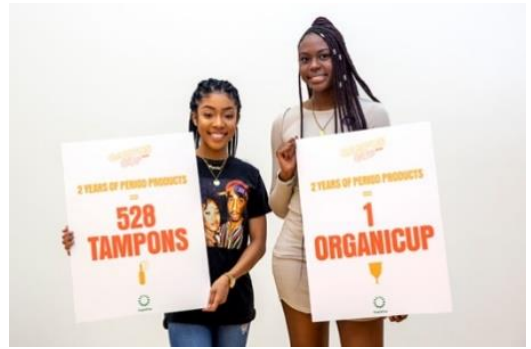

Gambar 5: Foto Instagram OrganiCup

Data Pertanyaan Purposive Sampling

1. Apa produk sanitasi yang anda pakai saat menstruasi? (Pembalut/Menstrual

Cup/Tampon)

2. Mengapa anda memilih jenis produk sanitasi tersebut?

3. Apa kekurangan dari produk sanitasi yang anda gunakan?

4. Apa kelebihan dari produk yang anda gunakan?

5. Apakah anda mengetahui tentang Menstrual Cup?

6. Jika iya, apa yang ada ketahui tentang Menstrual Cup?
7. Apakah anda menggunakan Menstrual Cup saat menstruasi? Alasannya?

8. Apakah anda mengetahui tentang brand OrganiCup?

9. Jika tau, dari mana anda mengetahuinya?

10. Apakah anda pernah melihat brand atau desain pada media promosi OrganiCup? Media apa yang sering anda lihat / jumpai? (Iklan di Sosial Media atau lainnya?

11. Bagaimanakah kesan, image atau pandangan yang timbul dalam benak anda ketika melihat desain media promosi OrganiCup?

12. Bagaimanakah kesan, image atau pandangan yang timbul dalam benak anda ketika melihat video media promosi OrganiCup?

13. Menurut anda, apakah yang membedakan OrganiCup dengan brand Menstrual Cup lainnya (dalam hal desain)?

14. Apakah anda tertarik untuk mencoba menggunakan OrganiCup saat menstruasi? Apa alasannya?

15. OrganiCup merupakan produk luar negeri yang mempunyai Official Store di Indonesia dan ada distributor lainnya yang bergerak dalam bidang ramah lingkungan. Jika anda tertarik menggunakannya, di manakah anda akan membeli Brand OrganiCup? Alasannya?

\section{HASIL DAN PEMBAHASAN}

Berdasarkan data yang sudah diperoleh dari responden sebanyak 20 perempuan, 2 dari 20 perempuan menggunakan menstrual cup sebagai alat sanitasi menstruasi, sedangkan 18 perempuan lainnya menggunakan pembalut dikarenakan sudah terbiasa, mudah dicari dan juga masih takut untuk mencoba menggunakan menstrual cup. 
Seluruh responden sebanyak 20 perempuan mengetahui apa itu menstrual cup sebagai salah satu alternative alat sanitasi menstruasi. 15 dari 20 perempuan mengetahui tentang brand OrganiCup dan sisanya tidak mengetahui. 12 dari 20 perempuan mengetahui melalui social media Instagram, dan sisanya mengetahui dari website resmi, youtube influencer, teman dan artikel berita.

Media promosi yang responden liat, 14 dari 20 perempuan sudah menangkap pesan yang dimaksud dan ingin disampaikan oleh OrganiCup yaitu kesan ramah lingkungan, alami, dan natural. Berdasarkan hasil, adanya peluang lebih dari setengah responden yaitu 12 dari 20 perempuan tertaik untuk mencoba menggunggunakan menstrual cup, sedangkan sianya terdapat 8 perempuan tidak tertarik karena alasan takut dan 2 perempuan beralasan masih ragu. Berkaitan dalam hal ini, adanya peluang untuk membeli menstrual cup dari OrganiCup karena 10 dari 20 perempuan memilih membeli melalui Official Store OrganiCup di Indonesia dengan alasan lebih mudah dijangkau dan terpercaya, sedangkan 5 perempuan memilih membeli melalui website resmi OrganiCup karena lebih terpercaya dan 5 perempuan memilih membeli melalui distributor (Sustaination) karena mudah dijangkau dan banyak produk ramah lingkungan lainnya.

\begin{tabular}{llr}
\multicolumn{4}{r}{ OrganiCup merupakan salah satu } \\
brand atau & merek yang \\
mengembangkan & alat sanitasi
\end{tabular}
menstruasi yang berorientasi pada konsep "The \#NewPeriod" dengan menggunakan bahan Medical Grade Silicon yang terbukti aman untuk tubuh. OrganiCup juga menghadirkan produkproduk seperti OrganiWipes dan OrganiWash yang berfungsi untuk membantu membersihkan menstrual cup saat atau setelah menstruasi.
OrganiCup memanfaatkan berbagai sarana komunikasi untuk menyampaikan pesan-pesan perusahaan kepada target marketnya. Media komunikasi yang dipilih tentunya menyesuaikan dengan perkembangan yang sudah ada saat ini. Banyaknya pesaing terutama local brand yang memasarkan produk yang serupa dengan berbagai konsep serta cara, adanya kekhawatiran akan kurangnya masyarakat kurang memliki kesadaran merk, menganggap visual dari media pemasaran OrganiCup kurang menarik sehingga pesan dari perusahaan tidak tersampaikan ke target market.

Berikut riset tentang faktor daya tarik visual terhadap orang yang belum memakai produk OrganiCup diantaranya:

1. Hampir semua responden mengatakan mengetahui tentang merek OrganiCup sudah mempresentasikan sebuah produk sanitasi yang ramah lingkungan karena terdapat kata 'organic' dalam OrganiCup.

2. Warna pada desain promosi OrganiCup di Instagram maupun Website sudah berhasil menyampaikan konsep OrganiCup yaitu "The \#NewPeriod" serta menyampaikan pesan bahwa OrganiCup kepada target marketnya, dengan memadukan warna-warna alam dan warna natural dalam media promosinya. Dengan ini dapat menarik minat beli konsumen.

3. OrganiCup menggunakan ilustrasi sebagai pengganti bahasa verbal sudah sesuai dengan target market, berupa fotografi maupun gambargambar yang bertujuan untuk menarik konsumen. Selain menggunakan unsur alami, OrganiCup memiliki beberapa program untuk perempuanperempuan yang mengalami 
kesulitan untuk mengakses produk sanitasi di negara berkembang sebagai unsur utama pada setiap medianya, model yang muncul di Instagram dan website adalah perempuan-perempuan dari belahan dunia yang merepresentasikan "Together we're making a positing impact on emvironmental, cultural, and social scales.". Sehingga target market dapat melakukan perubahan dengan membeli produk OrganiCup. Namun, untuk desain grafis setiap desain OrganiCup sudah terlihat benang merah di keseluruhan desain yang tanpa banyak menggunakan foto, sehingga pesan yang ingin disampaikan dapat diterima dengan baik oleh target marketnya.

4. Tipografi yang digunakan OrganiCup untuk pemilihan kata-kata dalam setiap promosinya sudah cukup menarik dan baik, menggunakan metode softselling dan bersifat mempersuasi dengan menampilkan data mengenai akibat menggunakan pembalut, sehingga target marget dapat dengan mudah beralih ke menstrual cup. Penggunaan tipografi dalam setiap desain maupun logonya, sudah konsisten dengan mempertahankan kesederhanaan dan menampilkan kealamian dari produk tersebut.

5. Tata letak dengan penempatan unsur fotografi, desain, tipografi sudah rapi , baik, mudah dibaca dan dipahami oleh target marketnya.

Dalam hal ini, secara keseluruhan desain promosi OrganiCup sudah baik dan dapat diterima oleh target marketnya, dibuktikan dengan sebanyak 12 dari 20 responden mengatakan bahwa tertarik menggunakan menstrual cup dan ingin membeli produk OrganiCup sebagai alat sanitasi menstruasi.

\section{KESIMPULAN}

OrganiCup merupakan salah satu brand yang produknya berupa menstrual cup asal Denmark yang sudah terdaftar di The Vegan Society dan AllergyCertified pada tahun 2017 dan telah memenangkan penghargaan "Best New Product" dan "Product Of The Year" pada tahun 2015. OrganiCup memanfaatkan media promosi seperti website, Youtube, Instagram dan program-program yang diusungnya untuk memberikan dampak positif bagi perempuan yang kesulitan mendapatkan akses produk sanitasi. Dalam hal ini, desain pada media promosi OrganiCup sudah mendapatkan brand awareness dari mahasiswa Unika Soegijapranata yang termasuk masih awam dengan produk sanitasi menstrual cup yang masih dianggap sebagai hal yang tabu di Indonesia.

Adanya kendala dalam cara pembelian, dikarenakan OrganiCup berasal dari Denmark, sehingga mahasiswa memilih membeli melalui official store, lalu dengan adanya distributor (Sustaination) yang secara tidak langsung sebagai media promosi OrganiCup. Media promosi dan pemahaman konsumen atas pesan yang akan disampaikan, sudah mendapatkan respon yang positif dan desain media promosi yang digunakan sudah efektif dan efisien sesuai target marketnya.

\section{DAFTAR PUSTAKA}

Cenadi, Chistine Suharto. 2020. Peranan Desain Kemasan Dalam Dunia Pemasaran.

Ayuranti, Gintari Dian. 2020. Perancangan Buku Visual Edukasi Menstrual Hygiene. 
Perdana, Oky Andhi. 2017. Faktor Yang Mempengaruhi Daya Tarik Visual Brand Larissa Aesthetic Center Terhadap Brand Awareness

Mahasiswa di Kota Semarang. 